
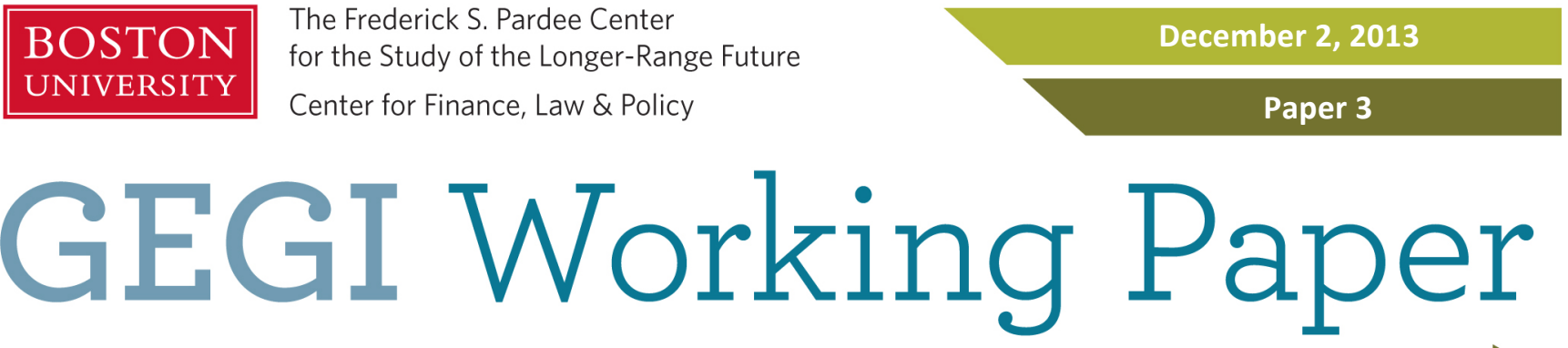

\title{
From Cocktail to Dependence: Revisiting the Foundations of Dependent Market Economies
}

\author{
Cornel Ban \\ Boston University, Department of International Relations
}

\begin{abstract}
Recent contributions to the comparative political economy of East European capitalisms have found that a distinctive variety of capitalism emerged in some new EU member states. The new variety has been dubbed "dependent market economy" (DME). This paper makes several contributions to this literature. First, it marshals evidence to show that this institutional variety now includes the political economy of Romania, a case previously excluded from it. More importantly, this analysis also finds that earlier scholarship on dependent capitalism has failed to capture crucial mechanisms of dependence created by transnationalized finance. Third, the paper suggests that some of the arguments made in the existing scholarship on the interests of foreign capital with regard to domestic innovation and labor training need to be qualified. Finally, by showing reflexivity towards select critiques of the dependent market economy framework, the analysis proposes by this paper is a self-limited attempt to bridge the differences between the varieties of capitalism and Polanyian analyses of capitalist diversity in semi- peripheral middle-income states.
\end{abstract}

\section{Introduction}

In the big picture of economic development during the past two decades, the European Union's new member states are often associated with fast and deep liberalizations (Gowan 1999; der Pij1 2001; Peck et al 2010; Farkas 2011). While neo-developmentalism shaped responses to globalization in Latin America, Asia or Russia (Khan and Christiansen 2010; Wengle 2012; Ban 2012), these European developing countries have played the liberal card instead. Yet this commonality conceals more than it reveals. The literature on capitalist diversity in Eastern Europe agrees that no homogenous "East European" variety of capitalism has emerged in this part of the EU. Instead, some economies replicated liberal or coordinated market economy patterns found in Western European or Asian liberal models, while others clustered around a specific institutional equilibrium called the dependent market economy (Lane 2005; Knell \& Srholec, 2006; 
2007; Mykhnenko, 2007; Birch and Mykhenko 2009; Nolke and Vliegenthart 2009; Hancke 2012). The picture gets even more nuances once state and politics are brought in via a Polanyian analysis (Bohle and Greskovits 2012).

This paper departs from the observation that the literature is unclear on whether the ongoing crisis has reinforced these countries' institutional complementarities or whether it has hastened their pre-crisis liberalization. This is an important question for the varieties of capitalism (VoC) scholarship, a scholarly tradition that has a penchant for predicting institutional stability but also prides itself on explaining change (Hall and Gingerich 2009; Hall and Thelen 2009; Schmidt 2009; Thelen 2009; 2012; Thelen and Busemeyer 2012; Jo Martin and Swank 2012). This gap gains a special valance in the context of the less settled institutional ecology of EU member states like the Baltic countries, Romania and Bulgaria. Unlike new member states that had liberalized earlier (Hungary, Poland, the Czech Republic), these political economies have gone through massive transformations a decade after the end of state socialism. In all of them, incremental changes taking place throughout the late 1990s and the first decade of the new millennium effected major liberalizations, as Bohle and Greskovits's recent tour de force shows (2012: 96-131; 182$201 ; 227-237 ; 248-255)$. But since the transformation of these economies was still in flux at the beginning of the post-Lehman crisis, one could expect them to be more likely than the "old" EU member states and early East European reformers alike to convergence towards the liberal variety of capitalism found in the UK or Ireland. Indeed, given their more fluid institutional order and their weak position vis-à- vis international pressures to liberalize, these countries are the most likely candidates to confirm Streeck's $(2009 ; 2012)$ skepticism that the liberalization steamroller can be resisted.

Within this "most likely" universe of cases, the case of Romania is the most interesting. In the late 1990s this was the East European economy with the most remarkable degree of institutional incoherence originating in the frictions between domestic interest groups and external actors, such as the Bretton Woods institutions and the IFIs. For example, at the time, the country had a weak state given to mercurial interventions that ranged between very liberal and very interventionist institutions. It also had mixed economy with a large public sector, privatization paradigms that hesitated between Anglo-Saxon and continental templates, weak employer associations and an activist but fragmented labor union movement that supported weak neo-corporatist institutions (Cernat 2006). The resulting institutional frictions made this "cocktail" variety of capitalism less competitive than the one used by its Western neighbors.

Yet the Romanian political economy saw a fast and deep transformation. Less than a decade later, powerful external and domestic integrationist forces moved this economic structure on the more liberal spectrum that lies between the "dependent market economy" model specific to East-Central Europe and the "(neo)liberal" one found in the Baltic States. Both these models rely on foreign capital as their main engine of growth. Yet while the former has been based around an institutional infrastructure meant to attract and maintain multinational firms, the latter's institutions were much more neutral towards the corporate sector. This paper argues that as a result of these transformations Romania had consolidated a model of capitalism that depended on multinational financial and FDI flows and used both liberalization and interventionism to reinforce this dependence. As a result, Romania ended its experimentation with cocktail capitalism and joined the camp of 
the dependent market economies represented by the likes of Poland, Slovakia or Hungary with results that were mixed at best.

This paper contributes to the literature on development and capitalist diversity in Eastern Europe in three ways. First, in addition to filling in the knowledge gap on the understudied case of Romania, it attempts to adjudicate and update the debate between the advocates of Romanian exceptionalism (Cernat 2006; Myant and Drahoukopil 2010) and those who see Romania as part of the neoliberal model typical of the Baltic states but with a weaker state (Bohle and Greskovits 2012). Second, and more importantly, it goes beyond the case of Romania and refines the literature on dependent market economies by unearthing dimensions of economic dependence that had not been considered in the original framework of the dependent market economy developed by Nolke and Vliegenthart (2009). Finally, it suggests that some of the interests attributed by existing scholarship to the multinational sector operating the dependent market economy should be revisited.

The study is organized as follows: after placing the paper in the literature on varieties of capitalism, a short historical background of the political economy of Romania is introduced in the first empirical section; then, in section two, the paper delves in the main body of the analysis by looking at the sources of investment dependence and the export profile of the Romanian economy; the comparative analysis of Romanian educational, innovation and corporate governance systems is addressed in sections three, four and five respectively.

\section{Capitalist Diversity in Eastern Europe}

\section{The state of the art}

Soon after independence the Baltic countries have adapted the liberal market economy (LME): financialized corporate sectors, a service-oriented economy, minimal state intervention, deregulated and mostly firm-level industrial relations, thin safety nets, education and training focused on the acquisition of general skills. At the other end of the spectrum is Slovenia's coordinated market economy (CME), with the state playing a key role in coordinating capital and labor, neo-corporatist industrial relations, a socialdemocratic welfare state, patient domestic capital for firms and dual system vocational education that delivered the specialized skills needed by Slovenia's sophisticated industry (Feldmann 2006; Adam et al 2009; Crowley and Stanojevic 2011; Hubner 2011).

In between these two extremes stands East-Central Europe, whose variety of capitalism cannot be captured by the existing lexicon due to the transformation of their economies into competitive assembly platforms for multinational corporations. Nolke and Vliegenhart call this dependent market economy (DME), an institutional hybrid seen as a variant of Ben Schneider's hierarchical market economy found in Latin America (Schneider 2009; Schneider and Soskice 2009). Its essence is a "specific type of comparative advantage that is not based on radical innovation (LMEs) or incremental innovation (CMEs), but rather on an assembly platform for semi-standardized industrial goods"(p. 679). Loaded with liberalizing tendencies, the DME model has a critical "nonliberal" nature as well. Its institutions provide not only for the efficiency of market actors, but also for their governance via a slew of institutional interventions orchestrated by the state which, despite 
some variation among the DME countries themselves (Duman and Kurekova 2012) end up privileging foreign capital over domestic capital and labor.

To demonstrate the distinctiveness of the DME variety, Nolke and Vliegenthart identify four institutional complementarities. First, MNCs don't get finance from domestic banks and run insider governance networks, as in the CME mode. Neither do they access finance on international markets and open themselves up to outside control by shareholders, as it is the case in the LME variety. Instead, "mother" companies control the subsidiaries in a hierarchical fashion and get finance from the same sources as the "mother" banks. In this way both finance and governance highlight the dependency relationship. Second, to keep costs down, MNCs prefer low taxes, a medium level of deregulation in the labor market and firm-level collective bargaining. The likelihood of their success in pushing for this is high given that East European countries have economic institutions that depend on their competitive profile for foreign investors.

Third, given that MNCs find it more efficient to transfer innovations to subsidiaries rather than invest in innovation-relevant skills or spend substantial amounts on vocational education schemes, as CME firms do. This dynamic is compounded by the fact that CME-style vocational education schemes require wide coordination between state, capital and labor, an institutional characteristic that has been minimized by the dominant postcommunist transition paradigm. As MNCs have avoided the kind of joint ventures demanded by developmentalist regimes in Asia, for example, the corporate headquarters of the "mother" firm can have a tight hierarchical control on innovation flows, thus trapping DMEs in a situation in which they remain assembly platforms for technologies developed by MNCs. Its institutional complementarities generate a comparative advantage in the assembly of manufactures of middle and high-levels of sophistication.

\section{The case of Romanian capitalism}

The state of the art on the case of Romanian capitalism is marked by the split between those who plead for Romanian exceptionalism and those who see Romania's political economy as part of a neoliberal "Baltic-Balkan" model. Speaking for the first camp, Lucian Cernat's excellent study provides an accurate picture of Romanian capitalism during the 1990s and finds it to be different from the more successful East-Central European and Baltic types (Cernat 2006). For all its merits, this study remains dated and can only be used as a benchmark for examining the starting point of the changes experienced by Romanian capitalism during the 2000s. Writing on the past decade, Nolke and Vliegenthart (2009) also see Romania as a country "stuck" in an underperforming cocktail capitalism. But the motivation of their rejection of Romania from the DME group is based on the Cernat study and a tangential piece of evidence (Bulgaria's poor performance in complex exports). ${ }^{1}$

\footnotetext{
${ }^{1}$ According to Noke and Vliegenthart, "while the ECE states have outperformed former CIS states such as Russia and Ukraine in terms of GDP per capita development, their superior economic performance (particularly that of Slovakia) becomes most obvious when compared with Bulgaria or Romania. The DME model of Slovakia has been much more successful than the rather incoherent "cocktail capitalism" of Romania. This superior performance is also exemplified by the export share of complex, human-capital intensive industries; from 1996 to 2005 it rose in Solvakia from 41 percent to 51 percent while it decreased in Bulgaria from 31 percent to 23. Slovakia also reports rapid development in high.tech exports from 2003 on. In contrast, the Bulgarian export structure has been relatively stable for the last five years, with some increase in heavy basic exports."
} 
Similarly, Myant and Drahoukopil $(2010 ; 2012)$ point to the export of simpler products as a reason for distinguishing Romania from Visegrad countries (Myant and Drahoukopil $2010 ; 2012$ ), Their evidence needs updating and refers to the share of FDI in the production of these goods, rather than their actual share in exports.In contrast to the literature on Romanian exceptionalism that draws on VOC, Bohle and Greskovits (2012) use a Polanyian conceptualization of capitalist diversity that stresses the role of the state. Their analysis suggests that Romania (and Bulgaria) have in fact converged on the (neo)liberal pattern seen in the Baltics. This leads them to talk about a "Baltic-Balkan" capitalism, albeit with the qualification that in Romania and Bulgaria governments' attempts to the same were more circumscribed by weaker states and various forms of mass politics. These authors open a sophisticated discussion on postcommunist capitalist diversity that "grafts" select insights from VoC and classical political economy. ${ }^{2}$ Yet their analysis of Romania underestimates the extent to which its integration in European capitalism differs from the Baltic pattern in terms of the export share of complex industries and the role of state interventionism in attracting FDI. For example, while their claims about state weakness are correct, their assertion that FDI inflows in Romania went to lowskill "sweatshop" industries and avoided complex manufacturing sectors (Bohle and Greskovits 2012: 207) needs to be reexamined in the light of recent developments.

This paper is the first study since Lucian Cernat's 2006 book that examines Romania in a systematic way. To this end, it uses primary evidence such as international financial media reports, Romanian public policy documents, analyses submitted by Romanian think-tanks and academics, interviews with key Romanian state and corporate actors carried out between 2008 and 2012, media reports and statistics issued by a wide diversity of actors inside as well as outside the country. The author also carried out interviews and recorded statements made by prominent policy makers and business leaders present at the Bucharest Forum, a top-level two-day seminar organized by the Aspen Institute in November 2012.

The empirical analysis carried out in this paper stays close to Nolke and Vliegenthart's analytical framework while acknowledging its limitations and trying to reassess Bohle and Greskovits' Polanyian analysis of Romania during the past decade. The paper agrees with those who argue the transplantation of varieties of capitalism to developing country contexts carries a great deal of problems. Chief among these is neglect of the politics of insertion in the global economy such as the dynamics of state capacity, political pluralism, the balance of class forces or the contingent choices of pivotal policy actors (Bohle and Greskovits 2012; Ebenau 2012; Drahokoupil and Myant 2012; Bruff and Horn 2012; Heller et al 2009). Such aspects constituted the core of classical works on dependent development (Evans 1979; Cardoso and Faletto 1979) and have been reintegrated in some recent research (Kohli 2009; Beckert and Jager 2010; Bohle and Greskovits 2012). But while the DME framework is an incomplete one, it is nevertheless helpful at identifying some of the central mechanisms of dependent development for an open economy that Polanyians are interested in as well. For example, both schools of thought are interested in the extent to which states can attract complex industries or manage labor relations.

2 While I find Bohlee and Greskovits's Polanyian plea to take the state seriously in discussions of capitalist diversity, for mundane considerations of word count I chose to leave out the complex analysis of state capacity that these authors undertake. 
By showing reflexivity towards select critiques of the DME framework, the analysis proposes by this paper can be read as a self-limited attempt to bridge the differences between the VoC and Polanyian analyses of capitalist diversity in middle income and semi-peripheral states. As such, while it leaves the systematic examination of critical aspects of the state's balancing of market and society (e.g. the strength and weakness of the state, the politics of business interests or mass politics) to future research, this study flags specific historical junctures where they become most manifest and highlights the relevance of specific aspects of state weakness.

\section{Background: From developmentalism to dependent development}

Historically, proto-developmentalist ideas were popular in Romania since late $19^{\text {th }}$ century but it was not until the right-wing authoritarian regimes that dominated Romania between 1938 and 1944 that state-led development was carried out in policy practice (Ban 2011). The apex of this historical pattern was socialist developmentalism (19491989), which was for the most part a local adaptation of the Soviet model. In addition to the well-known characteristics of the latter it emphasized a closer financial, trade and technological relationship with Western Europe. When this model collapsed under the weight of a debt crisis in 1982, the Ceausescu regime shifted towards a less open economic regime geared towards the payment of foreign debt and the eventual accumulation of domestic development finance (Ban 2012).

The first few years of democracy saw the shift towards a Romanian synthesis of embedded neoliberalism and neo-developmentalism. Between mid 1990 and mid 1991 the country's first democratically elected government initiated a massive drive to deregulate, privatize and liberalize the economy while striving to make large SOEs more competitive and craft neo-corporatist industrial relations in a difficult international environment marked by lack of access to international financial markets. This hybrid economic regime led to a transformational recession of unprecedented proportions in peacetime, leading to the collapse of the government.

The next five years were marked by the dirgiste part of the ex-communist party. It entailed a systematic attempt to institutionalize a more decisively heterodox neo- developmetalist regime constrained only by the temporary conditionalities of IFIs. Following macroeconomic stabilization and return to growth, the Vacaroiu government opted for an economic model based in macroeconomic activism and industrial policy targeted at big employers in the public sector and FDI investments situated at the medium and high level of industrial sophistication. Rather than aim for Baltic-style "bare" neoliberalism or Visegrad-style dependent capitalism, the main objective of this government was gradual transition to a neo-developmental policy regime in which the state, domestic capital and joint ventures with foreign manufacturing firms would balance each other out in a political economy where full employment remained a legitimate objective. This "transition neodevelopmentalism" took the country from recession to growth but failed to create the virtuous neo-corporatist and high redistribution cycles of Slovenia and was eventually ousted at the polls in late 1996. 
After 1996, a center-right turn in electoral preferences and the shift of the ex-communist towards the Third Way ushered in an economically liberal shift in Romania's political economy. A liberalization breakthrough undertaken by a new center right government with IMF assistance led to a second transformative recession and deindustrialization but had to be slowed down due to massive labor resistance. It was only once EU accession was secured and under a new ex-communist government committed to orthodox macroeconomic, trade, tax and welfare reforms that the economy saw a systemic transformation towards a dependent reindustrialization agenda. This transformation has been the result of over a decade of dramatic domestic and international reorganizations of the domestic institutional landscape. The economically liberal turn in Romanian politics after 1996 plunged the country into a deep recession whose effects were magnified by the Russian and East Asian crisis of 1998. After four years of reforms and labor strife that brought the government on the brink of declaring a state of emergency and put tanks in the streets, the signs of recovery remained weak. What saved the liberal project from its implosion was Romania's EU integration, which began in 2000. The adoption of EUmandated economic institutions and privatizations of the "pearls of the crown" (banks, utilities, energy, large manufacturing) as well the uncertainty-removing effects of the expected membership pumped 100 billion in the Romanian economy, quadrupled the country's exports and arrested the process of deindustrialization. EU integration strengthened the hand of neoliberal reformers who found in the EU few limits on how far they could shrink state and social solidarity institutions.

This transformation was taken much further after 2004 by an ideologically radicalized liberal-conservative coalition. Under the Tariceanu and Boc governments (2005-2011) the neoliberal transformation of Romanian society and economy was taken away from the "embedded neoliberalism" of East-Central European countries countries and in the direction of libertarian experimentalism pioneered by the Baltic countries in the late 1990s. By achieving growth rates higher than those of the trailblazers of liberalization (Poland, Hungary and the Czech Republic) throughout the 2000s, Romania's dependent market economy model seemed vindicated. Yet by shrinking capital inflows and external demand while compressing domestic demand the Great Recession has called into question this model and left policymakers without robust means of intervention.

\section{Dependent investment}

Nolke and Vliegenthart (2009) argue that one of the defining features of DMEs is that they are heavy importers of capital. In other words, the primary source of investment is FDI, not the stock market (LME) or domestic banks (CMEs). This characteristic gives DMEs a higher level of external dependence on foreign economic cycles than in LMEs or CMEs. Romania is no exception. As figure 1 shows, during the 2000s the Romanian economy began to converge with the DME profile along the basic indicators used by Nolke and Vliegenhart. Between 2002 and 2010 no less than 106 billion euros entered Romania, representing FDI and financial inflows, contributing to a threefold increase of the GDP. Specifically, from representing 10 percent of GDP in 2000, FDI grew to nearly half of it in 2010 to the point that it plays a critical role in gross capital formation today. Basically for every billion of GDP growth, the economy received 1.4 billion in foreign investment. 


\begin{tabular}{|l|l|l|l|l|}
\hline & $\begin{array}{l}\text { FDI inward } \\
\text { stock as } \\
\text { percentage of } \\
\text { GDP (2010) }\end{array}$ & $\begin{array}{l}\text { FDI as } \\
\text { percentage of } \\
\text { gross capital } \\
\text { formation } \\
(2008)\end{array}$ & $\begin{array}{l}\text { Domestic credit } \\
\text { to private sector } \\
\text { as percentage } \\
\text { of GDP (2008) }\end{array}$ & $\begin{array}{l}\text { Mapitalization of } \\
\text { listed } \\
\text { companies } \\
(2007)\end{array}$ \\
\hline Hungary & 71 & 22 & 69 & 35 \\
\hline Czech R. & 67 & 13 & 50 & 40 \\
\hline Slovakia & 58 & 20 & 44 & 8 \\
\hline Poland & 41.2 & 14 & 49 & 48 \\
\hline Romania & 43.9 & 20 & 45 & 26 \\
\hline
\end{tabular}

Sources: FDI inward stock as a percentage of gross domestic product (1990-2010), UNCTAD Communications and Information Unit, FDI/TNC database, viewed 11th August, 2011, <http://www.unctad.org/fdistatistics $>$; visualized at http://chartsbin.com/view/2271; for market capitalization see www.tradingeconomics.com;

To better understand the concrete implications of these figures, this section will unpack the importance of foreign capital by examining separately FDI and financial investments. The share of FDI in the export sector is a good proxy for external competitiveness while its role in the financial sector affects the availability of capital to small and medium firms in the economy. The analysis places Romania within the DME camp but with several qualifications. Most importantly, the section argues that there are two categories of DMEs: small export economies, where exports account for 80 percent of GDP (Czech Republic, Slovakia, Hungary) and middle-sized economies, where they account for 30 to 40 percent. Along with Poland, Romania fits the latter category.

\section{Foreign direct investment and complex exports}

The trade off between the dominant position of foreign capital and the capacity to harness FDI to increase the complexity of exports appears to be the fundamental characteristic of the DMEs (Nolke and Vliegenthart 2009) and "embedded neoliberal" regimes (Bohle and Greskovits 2012). While Romania did not fit this profile in the early 2000s it certainly did a decade later and, as such, it differs from the Baltic group with which Bohle and Greskovits associate it (2012: 223-237; 251-258). Multinationals churning out complex products gained a strong foothold in the economy and became the main engines of export-led growth. Like the average DME, Romania has a large share of industry in its GDP. Between 2004 and 2008 the growth of the turnover rate-or the total of all sales- in the manufacturing sector grew faster in Romania not only relative to the liberal Baltic 
models, but also relative to all the other DMEs (Eurostat 2012). Energy, automotive, steel and chemicals dominate the top 50 firms by size. ${ }^{1}$ At 21 percent of GDP, the Romanian manufacturing sector's share of the economy puts Romania in the same league with Slovenia, Slovakia and Hungary, rather than with the less industrialized Baltic states or Bulgaria (World Bank 2012).

The transnationalization of the Romanian economy was the result of identifiable political decisions. Throughout the 2000s Romanian governments consciously followed the DMEs' attempt to convert the core of the economy into an assembly platform for MNCs. This strategy was facilitated by the ascendancy of liberal economic ideas on both sides of the political spectrum and was strongly incentivized by chronic shortages of capital in the public sector and the weakness of domestic private capital (Ban 2011). The incorporation of Romania's industrial economy into the assembly platforms of MNCs yielded immediate results. Arguably, the main drivers of the spectacular growth of the 2000s were the exceptionally fast catch-up in productivity enabled by foreign direct investment and integration into cross-border European production networks. ${ }^{3}$ In turn, these processes started a convergence process with the export-led DME economies. By the end of that decade, Austrian, German, French and Italian firms (in this order) accounted for about two thirds of Romania's exports. By 2011, of the top 100 exporters, 96 were subsidiaries of multinationals. Thanks to such firms, exports boomed: compared to the 1990s, exports in 2010s were 600 percent larger. When austerity depressed domestic demand after 2010, growth projections were tied strictly to export dynamics (Canagarajah et al 2012).

Most importantly, my analysis challenges the popular thesis that Romania's incorporation in the European economy is dominated by exports of low complexity. By 2012 Romania was no longer the low-end textiles-and-steel territory of the 1990s. The bulk of FDI was invested in energy, chemicals, means of transportation, industrial equipment, mining and steels. Manufacturing attracted most FDI (44 percent), as the low wage army of labor with solid engineering skills made possible by the modernist educational philosophy of Romanian socialism made possible a boom of Western investment in manufacturing, from cars to aircraft parts. International brands like Renault or Ford established some of their largest plants in Romania by purchasing off-the-shelf factories built during socialism but others (Continental, Nokia) built new ones. Textiles and footwear, the erstwhile export niche of the Romanian economy, received only 1.4 percent of FDI, three times less than the IT sector. ${ }^{4}$ Like in the DMEs and unlike in the Baltic countries, this outcome was as much the result of a decades-long experience with industrialization as of industrial policies targeted at multinationals that invested in activities of medium and high complexity.

In relative terms, this transformation makes Romanian exports quite similar to the DME model. In the ranking of export complexity done by MIT's Economic Observatory, the level of complexity of Romanian exports has gone from a low level in the early 2000 s to

\footnotetext{
3 According to Eurostat, Romania had the highest productivity growth in the EU during the 2000-2011 period.

${ }^{4}$ Marin Pana, "A growth engine: FDI and their role in the economy from Roman to Boc/Un "motor" de creștere: Investițiile străine și aportul lor la economie, de la Guvernul Roman la Guvernul Boc, Curs de Guvernare, September

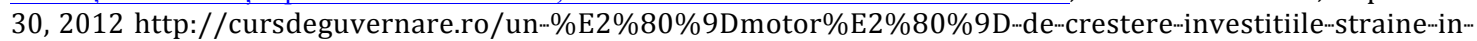

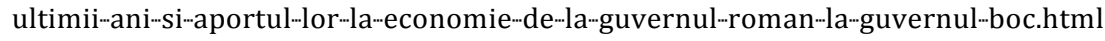


ranking close to the Netherland's, lower that that of Hungary, the Czech Republic or Slovakia as well as higher not only relative to Bulgaria and the Baltics, but also than in Spain and Portugal. ${ }^{5}$ Within the DME world, Romania's export profile is virtually indistinguishable from Poland in terms of their complexity. In contrast, the Baltic states and Bulgaria have export profiles that put them in the company of commodity exporters (Brazil, Canada), traditional low end manufacturing economies (Portugal) or war-ravaged economies (Lebanon, Serbia, Bosnia).

\section{Figure 1: What did Poland Export in 2010?}

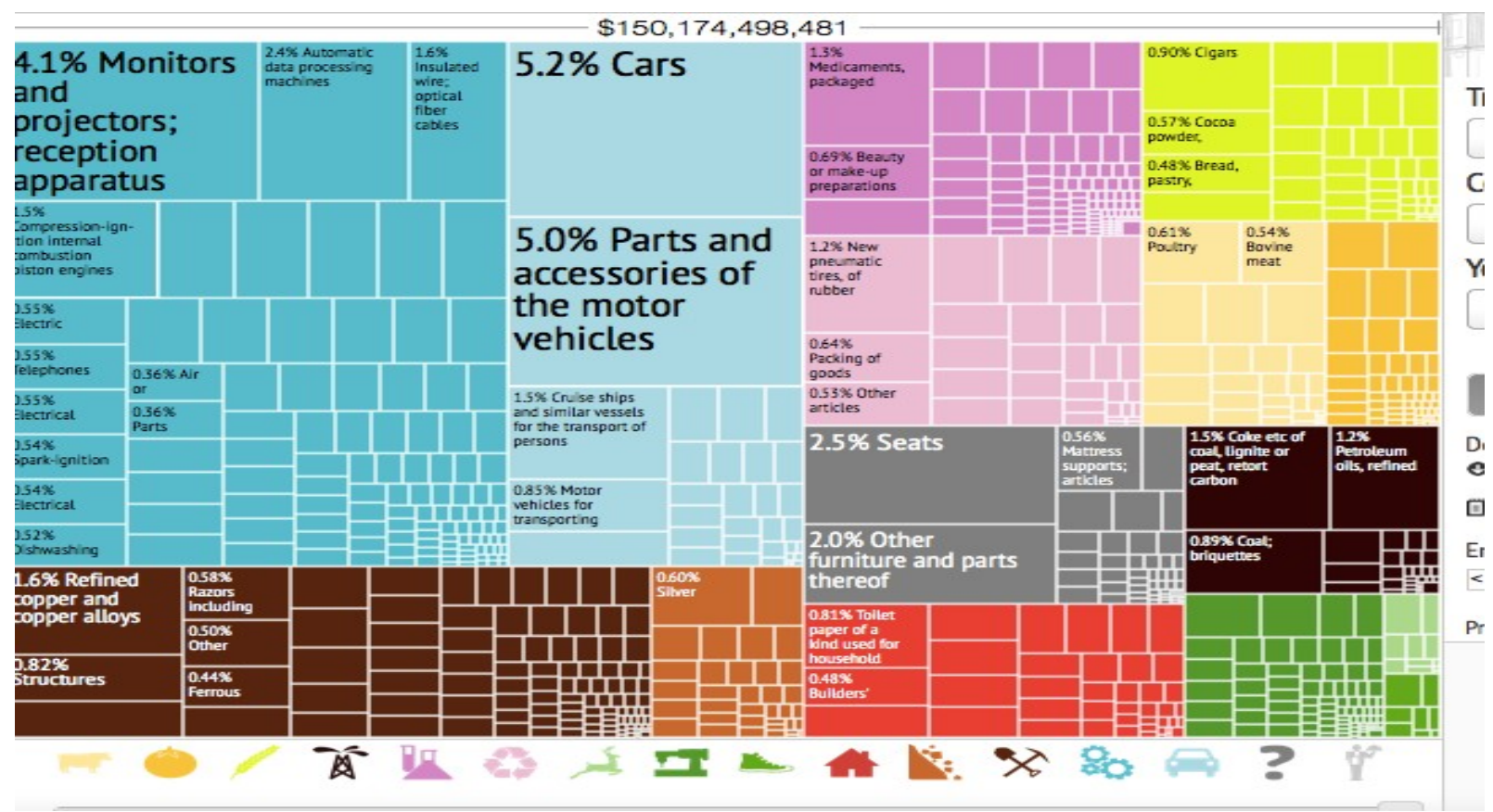

\footnotetext{
${ }^{5}$ MIT, The Observatory of Economic Complexity, http://atlas.media.mit.edu/rankings/
} 
Figure 2: What did Romania export in 2010?

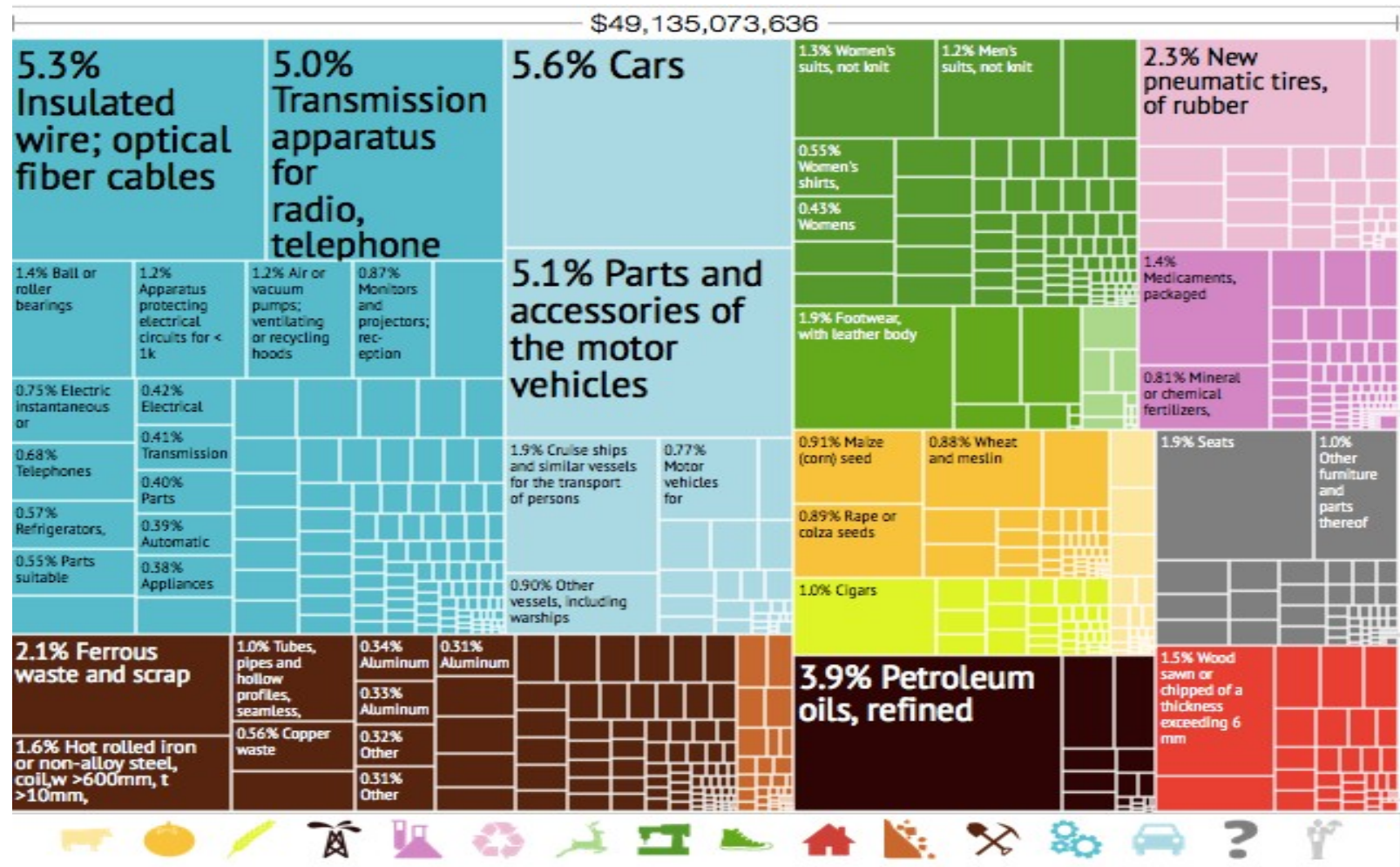

During the 2000s, Romania also began to look more like Poland than the small export oriented economies of Slovakia, the Czech Republic or Hungary when it comes to the makeup of FDI flows: three times more investment went into commodities and banking than on complex products. Also, while migrant remittances play a minor role in DMEs (except Poland), they matter significantly in the Romania and Poland (Ban 2009). ${ }^{6}$

Like in the other DMEs, a wide array of Western firms that are pivotal suppliers for the global car industry opened up large operations in Romania. When Renault announced that it would open a large research and development facility close to Bucharest and began a hiring spree in the engineering departments of Romanian campuses, many felt that the developmental shift from assembling Western products to designing and manufacturing them locally was within reach. Moreover, even in the midst of the crisis, a wide survey of hundreds of investors found that IT, telecom, energy and pharmaceuticals were expected to be the substantial contributors to future growth and that Romania was perceived in investor circles as a country whose emerging competitiveness clusters signaled a high likelihood of more high-tech development. ${ }^{7}$

But the role of foreign capital should be further qualified by the fact that the state companies remain major contenders in some industrial sectors. Thirteen SOEs account for 20 percent of the turnover rate in the top 100 industrial firms and in terms of assets, six firms from the top ten are state-owned, with one state company (Hidroelectrica)

\footnotetext{
${ }^{6}$ Data processed by Myant and Drahoukopil (2012).

${ }^{7}$ Ernst \& Young, European Attractiveness Survey, 2012,

http://www.ey.com/Publication/vwLUAssets/Attractiveness 2012 europe/\$FILE/Attractiveness 2012 europe.pdf
} 
boasting assets worth 7 times more than the biggest multinational (Automobile Dacia Renault). In terms of net corporate profits, the Austrian-owned national oil company (Petrom) is followed by two state-owned energy companies, whose combined profits are almost as high as of the rest of companies in the top ten of Romanian corporations. ${ }^{8}$ Finally, the most important two employers in the corporate sector are state-owned (mail and rail), with the national oil corporation owned by Austrian OMV and the internationally successful Dacia plant owned by Renault coming next. This situation is not unlike that of Poland (not to mention Slovenia), yet by 2013 many of these large state industrial operations were up for sale.

Very much like Hungary or Slovakia a decade before, during the 2000s Romania offered manufacturing FDI a genuine "competition state" whose weak capacity in providing modern infrastructure on a par with its regional competitors was matched by its willingness to subsidize the internationalization of Romania's productive base through uncompetitive privatizations carried out at large discounts, tax breaks, subsidized energy or credit guarantees. State aid was coherently and competently managed and its terms were designed to target at multimillion dollar multinational investments with high multiplier effects and know-how trickle down. The biggest investments in the automotive sector (Renault, Ford, Delphi, Bosch, Draxlmaier, Honeywell, Pirelli), aircraft (Premium Aerotec), white goods (deLonghi), oil equipment (Lifkin), electronics (Nokia) and IT (IBM) were completed only following the granting of significant state subsidies. ${ }^{9}$ State aid schemes were further institutionalized after during the crisis through several emergency decrees. ${ }^{10}$

Subsidies were important but the bulk of FDI-friendly interventions took place elsewhere. Rather than be carried out in the spirit of EU-advised competition, the privatization of utilities with West European capital offered instead opportunities for horizontal and vertical concentration (Haar and Marinescu 2011). Privatizations at discount prices were common. For example, the publicly-owned oil giant Petrom, the only east European oil company that sourced 75 percent of crude from domestic oil production, was sold in 2004 to Austrian-owned OMV at a woefully undervalued price. ${ }^{11}$ The Romanian boom in renewable energy was fueled by government-issued "green certificates" 12 and many greenfield investments were carried out only following land grants and the public provision of utilities and transportation infrastructure. Energy sold cheaply by state- owned hydropower and subsidized coal power stations benefited extensively foreign investments in energy-intensive industries like steel and aluminum. ${ }^{13}$

\footnotetext{
${ }^{8}$ There is not a single firm owned by a private Romanian entity in top 10 .

${ }^{9}$ Ministry of Finance, Lista agenților economici care au primit acorduri de finanțare emise de MFP în anul 2012 în temeiul H.G. nr.753/2008, până la data de 21 noiembrie 2012, http://www.mfinante.ro/listafinantare.html?pagina=domenii

10 See H.G. 753, 1680 (in 2008) and 797 in 2012. Available at http://www.mfinante.ro/listafinantare.html?pagina=domenii

11 The Romanian Intelligence Service informed the Parliament that the Romanian state lost nearly I billion dollars from the sale. SRI, Raport nr. 1255, December 8, 2007.

12 Romania continues to be the world's 10th most attractive destination for investments in wind power according to global financial consultancy Ernst \& Young (Ernst \& Young Country Attractiveness Index 2013). See also "Winds of fortune blow through Romania" Financial Times, March 16, 2011.

13 "Romania May Have Given ArcelorMittal Unlawful State Aid" Bloomberg News, July 6, 2012,

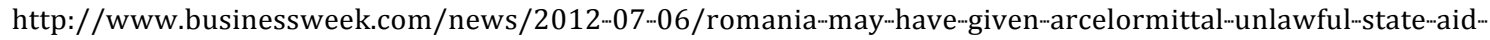
eu-says
} 
The post-Lehman crisis highlighted the limits of dependent industrial investment. FDI dropped from an average of 6 billion a year to around 2 billion a year after 2009, while public debt increased by 400 percent between 2008 and 2011. Once removed the vast net of perks with which FDI was attracted, multinationals confronted the Romanian government and society with a rude awakening to the reality of disloyal capital. A few high employment multinationals cut down their operations as a result of falling demand in Western Europe. Others (Finnish Nokia and Russian Mechel) simply used up the FDI incentives and then swiftly moved out to economies with even lower wages. In late 2012 foreign firms for whom subsidized power produced by state-owned hydro plants was a major reason for moving to Romania were considering moving out as well. ${ }^{14}$ Moreover, the fiscal crisis of the state forced out revelations that the oligopoly of five Western European energy companies saved 250 million euro by not investing in the modernization of the power grid infrastructure they purchased with a discount in $2005-08,{ }^{15}$ often causing interruptions in the power supply. ${ }^{16}$

In short, during the past decade Romania has acquired some of the defining feature of the industrial sectors of DMEs and has done so largely through FDI-focused industrial policy measures and, as the next section shows, failure to act on the dependent status of its innovation systems. As the next section shows, Romania follows the DME pattern in finance as well. This is the result of the dominant position of the subsidiaries of foreign banks in the Romanian financial sector as a result of a particular mode of financial transnationalization that affected Eastern periphery differently than the Southern one. It is to the analysis of this issue that I now turn.

\section{Dependent finance}

If during the 2000s banks from the EU "core" banks made fortunes in Southern Europe largely through wholesale markets that boomed under the impetus of euro convergence (Gabor and Ban 2012), in Romania and Eastern Europe more generally they simply bought existing state-owned institutions. The results of the ensuing shopping spree were spectacular: the share of foreign-owned assets in total banking assets grew to 85 percent foreign ownership. While in 1998 five state-owned banks had 71 percent of banking assets, by 2008 the public banking sector had shrunk to 5.3 percent. Among the ten largest banks, only two (state owned CEC and privately owned Banca Transilvania) were domestic on the eve of the Lehman crisis. In contrast, in 2008 the subsidiaries of foreign banks had 89 percent of the market share. In the DME category, only the Czech Republic reported higher numbers. ${ }^{17}$ As a result, over 80 percent of credit originates from the Eurozone.

\footnotetext{
${ }^{14}$ Interview with Doru Lionăchescu, consultant, Managing Partners, EvZ, http://www.evz.ro/detalii/stiri/2012*-

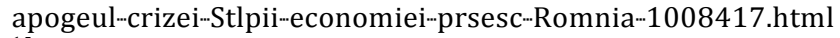

${ }^{15}$ Ziarul Financiar, February 7, 2012. Available at http://www.zf.ro/companii/cel-mai-important-proces-pentru-statelectrica-cere-la-paris-penalitati-de-250-mil-euro-de-la-cez-enel-si-e-on-10550057

${ }^{16}$ Investigation report undertaken by the Commission for the Privatization and Management of State Assets, no 816, May 31, 2010. On file with the author.

${ }^{17}$ UniCredit Group, CEE Banking.-still the right bet, July 2008, www.bankaustria.at/en/index.html
} 


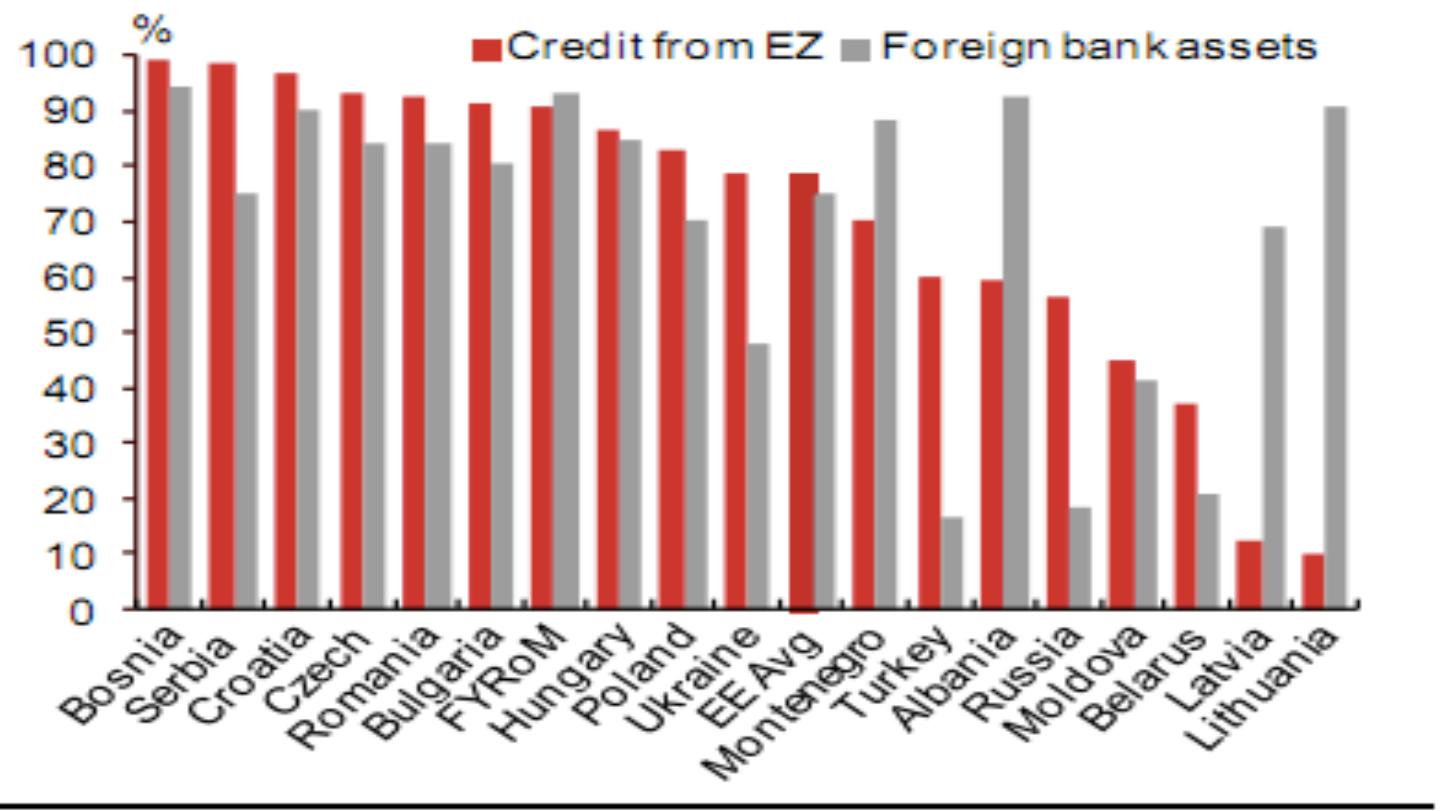

Source: BIS, EBRD, Nomura Emerging Markets Research

The basic idea behind this transformation was that by selling their banks to brand names in Western banking the Eastern Europeans would shoot several rabbits with one shot: (a) break the links between government incumbents, state banks and state-owned enterprises responsible for cycles of non-performing loans, bank recapitalizations, and inflation (b) avoid the Russian and Ukrainian scenario in which local insiders would snap state banks for a song and build oligarchic business empires filled with bad politics (c) reduce the uncertainty of the EU membership negotiations by privileging buyers from the EU member state, (d) get a brand new off-the-shelf banking sector decked out with modern Western technologies and, most importantly, (d) address a decades old economic frustration of electorates-squeezed private consumption-by making consumer credit abundant and easy. Sensible people thought at the time that all this signaled international credibility, helped ease the Easterners from the EU waiting room into the boardroom and riveted the region's financial systems with powerful banks that were too big to fail at home.

Most importantly, however, this transformation supplied governments with a strong economic source of domestic legitimacy. Consumption levels depressed by restrictive macroeconomic policies of dubious benefit for the economy as a whole (Gabor 2012) recovered. From a paltry 5 billion euro in 1999, private debt went up to 200 billion euro 
in 2009. As a result, overall debt increased five times, from 10 billion in 2000 to nearly 50 billion in 2008. Since Lehman, the figure doubled, to nearly 100 billion in $2012 .^{18}$

Dependent banking was a quick fix for the socio-political crisis of Romanian postcommunism, yet it failed to serve the Romanian economy well in the medium term. Like in the other DMEs, foreign ownership in the financial industry blew a huge consumer and real estate credit bubble while making only a marginal contribution to industrial investment or the small and medium enterprise sector. As Gabor (2012: 101105) shows, lending to the firms in 2008 was as high as in the 1994-1996 period, when the banking sector was domestic and predominately state-owned. Far from supporting the local small and medium entrepreneurs, the transnationalized Romanian banking sector had only 15 percent of this sector of the economy on its books. Moreover, while in 2000 industry received 56 percent of credit, by 2008 this share fell to 20 percent, outpaced by credit to households and the service sector. In contrast, in 200812 percent of credit was financing the construction sector.

As for MNCs, rather than get their finance from "local" banks, they brought their credit lines with them. ${ }^{19}$ By 2008, cross-border intra-company loans reached almost 14 percent of overall credit to corporations (Gabor 2012: 101). Also, since easy credit benefited mostly an emerging middle class (about 20 percent of the population by most estimates) whose consumption patterns stressed imports, the local subsidiaries of foreign banks assembled together the main engine of the East European crisis: gaping current account deficits (Voinea 2012). Moreover, foreign banks funded a massive increase in construction expenditures by becoming the originators of a mortgage lending in euros and other "hard" currencies, owing to the importance that the favorable interest rate differential played in the profit strategies of the foreign-owned banking sector. ${ }^{20}$

The banking crisis of 2008-2009 and the collapsing confidence of international direct investment after 2008 sheared Romania's development model of its strengths. Indeed, while dependent development made Romania prone to FDI and portfolio investment booms on the upswing, it reversed them just as dramatically during the post-Lehman downswing. The result was a structural economic crisis that began as a banking crisis magnified by current account imbalances and followed by a dramatic cut of FDI inflows (Gabor 2009). Foreign banks that owned the financial sectors started to deleverage at home and considered pulling out to supply funds to mother banks hit by the Lehman crisis; the West European crisis depressed the optimism of foreign direct investors, leading them to abruptly cut investment flows to Romania; to boot, the countries where most Romanian remittances originated (Italy, Spain, Ireland) faced a dramatic surge in unemployment. With its coffers emptied by pro-cyclical tax cuts adopted before the crisis, the conservative government did not have ready resources to act countercyclically even in the unlikely ideological event that it wished to.

\footnotetext{
${ }^{18}$ Data supplied by the national Institute of Statistics (INS).

${ }^{19}$ Interview with Sorin Mandrutescu, AmCham Romania, Bucharest, November 2012; interview with Andrei Radulescu, stock broker, December 2012.

20 Interview with Andrei Radulescu, Bucharest stock broker, December 2012
} 
At this point the subsidiaries of foreign banks activated previously unexplored mechanisms of economic dependence that were bolstered by the EU and the IMF. First, in the fall of 2008 their treasury and currency desks have actively orchestrated speculative attacks against the Romanian Leu (Gabor 2009; 2013). Second, in early 2009 that international banks reduced their cross-border loans to East European banks, with the greatest reductions affecting the most liquid of them (Slovakia and the Czech Republic), in a move that a BIS report termed as suggestive of the fact that "some parent banks may have temporarily used these markets to maintain liquidity at home" (Dubravko Mihalijek 2009 , p. 4). In relative terms, the reduction in cross-border banking flows as a percentage of GDP was about as big for ECE in 2008-2009 as it was for Asian countries in 19981999 (p.7). To alleviate the liquidity crunch, in 2009 central banks in Hungary, Poland and Romania tried to convince the ECB to broaden the list of eligible collateral for its monetary operations by including government bonds issued in local currency in exchange for haircuts to these non-euro government bonds. The ECB rejected the suggestions. ${ }^{21}$ The panic of foreign banks who bought up local banks and now faced massive losses and the possibility of unbundling currency pegs was so great that 2008-9 many of them threatened to use the exist option, triggering fears that the ensuing capital outflow would shut down the economies of the region. The panic in early 2009 was so big that foreign banks were ready to overlook the fact that the Romanian lending market had a great potential: it was only worth around 40 per cent of GDP, whereas it's 150 per cent elsewhere in the region. ${ }^{22}$

Third, in the specific conditions of the crisis of early 2009 the transnational banks constrained policy autonomy through joint international policy conditionality. This happened as the E.U. and the IMF intervened and orchestrated a massive bailout of the financial systems of Romania, Latvia, Hungary, Bosnia and Serbia. Ironically, it was in Vienna, the trigger of the Great Depression, where an agreement was signed in 2009 with banks, the European Central Bank, the European Commission, the EBRD, the IMF and the states in question sitting around the table. The core of the agreement was that West European banks committed to stay if ECE governments reiterated commitments to austerity and stabilizing the banks' balance sheets while the IMF and the E.U. put the corresponding bill (fiscal austerity, high interest rates, constraints on mortgagees' rights, recapitalization I.M.F./E.U. loans deposited with the central bank) on the balance sheet of the states. $^{23}$

The Vienna Agreement established a public-private international financial regime in which the IMF, the EU and the banks exercised a form of shared conditionality over the policy decisions of Romania, thus reinforcing the dependent status of its variety of capitalism. For the government, this meant reliable buyers of its bonds and a brake on the disorderly withdrawal of foreign banks. For the banks, it meant protection against the collapse in domestic demand made even more dramatic by the austerity included in the

\footnotetext{
21 “And justice for all: in emerging Europe," Financial Times, November 7, 2011.

${ }^{22}$ Interview with Vlad Muscalu, economist at ING Romania, Financial Times, February 13, 2012.

${ }^{23}$ It was no surprise then that as the West European sovereign debt crisis hit, another major vulnerability emerged: that foreign banks in Eastern Europe could become the transmission belts for the troubles of Western sovereigns. Following Greece's tailspin and Austria's downgrading in the spring of 2012, S\&P turned Romanian bonds into junk status because the Romanian banking sector had too much Greek and Austrian financial capital.
} 
bailout package. It also meant protection against constraining regulatory interventions (Kudrna and Gabor 2012) and the attempts made by consumer organizations in 2010 to lend erga omnis value to court rulings finding abusive clauses in bank contracts. Faced with the prospect of hundreds of millions of euros a year in loses, ${ }^{24}$ banks demanded and obtained IMF and central bank protection against Romanian courts. ${ }^{25}$ For now, the new crisis resolution regime institutionalized a transnational financial and macroeconomic policy dependence by keeping all Romanian governments committed to the Vienna agreement.

Third, the dependent status of Romanian capitalism has been further magnified by the workings of the sovereign-bank nexus afflicting the economies of Greece and Austria. ${ }^{26}$ Romania is exposed to Greek banks, who control of sixth of assets in the banking sector, with each crisis in Athens having the largest Europe-wide repercussions on the Bucharest stock of exchange. ${ }^{27}$ Closer to home, in the summer of 2011 Greek subsidiaries in Romania used Emerging Europe interbank and swap markets to fund parent banks in Greece at the Romanian rate ( 6 percent), with rates in Greece being in the double digits. ${ }^{28}$

Under pressure from a downgrade and without adequately consulting with the Romanian government, in 2011 the Austrian government recommended-or exerted "moral suasion" as Vienna put it- that Austrian banks limit their exposure in emerging Europe by calling them to issue loans not in excess of 110 percent of the financing they raise locally. This sent shockwaves in Bucharest, ${ }^{29}$ as according to Fitch Austrian banks own 31.5 percent of Romania's bank assets. Faced with such problems the Commission and the IMF were less successful at extracting Vienna 2.0, a commitment for Western banks to maintain their commitments in Romania and the rest of the region. ${ }^{30}$ In response to Austrian and Greek troubles and despite the upbeat outlook on the economy, in November 2011 S\&P downgraded Romania, a decision bolstered by the fact that foreign denominated debt exceeded 60 percent and foreign institutions owned 85 per cent of total banking sector

\footnotetext{
${ }^{24}$ In 2013 the Romanian Banking Association (RBA), the financial sector lobby, estimated loses at 600 million euro a year in case new legislation allowed court rulings to have erga omnes power in cases where at issue were abusive contract clauses. Ziarul Financiar, November 21, 2012; http://www.zf.ro/banci--si--asigurari/ingrijorare--printre--

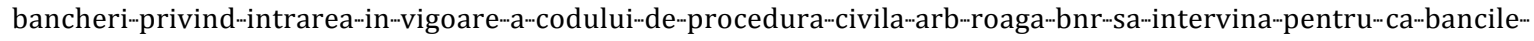

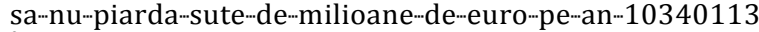

${ }^{25}$ The in-"house report of the RBA explicitly acknowledged the role of the IMF and the central bank in limiting court jurisdiction and regulatory moves deriving from court jurisprudence. Ziarul Financiar, November 21,

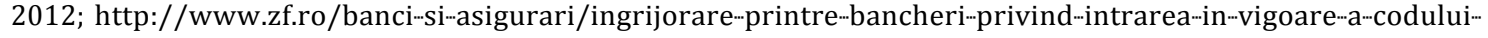

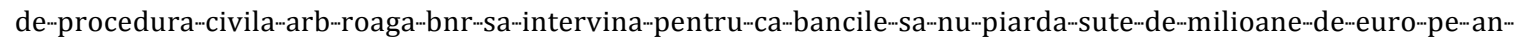
10340113

${ }^{26}$ According to Fitch, Austrian banks dominate Romanian banking, holding around 40 per cent of total market share, while Greek banks' subsidiaries account for 24 per cent of capital and 14 per cent of the assets of the banking sector.

27 "CEE: Bearing the brunt of the storm," Financial Times, May 14, 2012.

28 "Honey, I shrunk Emerging Europe" Financial Times, November 4, 2011.

${ }^{29}$ Romanian President Traian Basescu told foreign banks "You have made huge profits and if you are now getting ready to leave Romania unfinanced during the crisis we will think it is an act lacking fair play towards Romania (...) I don't want to believe we will be left to pay the bills of banks' greed. There are European mechanisms. I urge you to use these mechanisms instead of choking the Romanian economy by reducing capital inflows." Cited by Reuters, November 24, 2011, http://uk.reuters.com/article/2011/11/24/idUKL5E7M018J20111124

${ }^{30}$ Stefan Wagstyl, "Austria clarifies plan to curb eastward lending," Financial Times, January 17, 2012
} 
assets. As Standard and Poors put it 'these subsidiaries are autonomous from their parents, which we believe will likely limit spillover effects if confidence in the Greek banking sector weakens further. In our view, however, there is a risk that if foreign parent banks run into difficulties they may significantly reduce cross-border exposure to their subsidiaries, thereby reducing credit activity." ${ }^{31}$ The situation was potentially catastrophic. At the time Nomura estimated that foreign banks would suck 1.2 percent out of the Romanian GDP in the event of massive deleveraging, which was more than the total level of FDI in 2012. There was also a high risk of firesale, with no buyers in sight ${ }^{32}$ and Basel III capital requirements looming large in the immediate future.

So far the paper showed how dependent industrial investment made Romanian exports more complex, placing the economy squarely in the DME camp. Yet the crisis brought to the fore the limits of reliance on FDI while the other DME characteristic (dependent finance) armed the mechanisms of the post-Lehman crisis in Romania and acted as a transmission belt for the sovereign debt crisis of the European periphery. What is more, the DMEs reliance on foreign capital for establishing strong domestic innovation systems able to generate domestic high value added activities experienced in the case of Romania one of its most disheartening manifestations.

\section{Dependent innovation systems}

Nolke and Vliegenhard argue that significant research and development (R and D) investments are not necessary in DME economies whose competitive advantage lies in the assembly of semistandardized goods. What matters is whether the economy has institutional complementarities that ensure profitability within MNCs with operations on the ground. In this perspective, the dynamics of domestic innovation capabilities is peripheral to the strategies of multinational capital. As such, dependent innovation systems represent an important development trap. Romania fits the DME profile quite well in this regard. Aside from a few industrial niches of excellence, Romania remains an assembly platform for innovations developed abroad. Indeed, to the extent that Romanian exports have become more complex and diversified, this had little to do with domestic $\mathrm{R}$ and D. There has also been very little technological trickle down from FDI flows. As in the case of the DME countries, FDI was focused on the use of local labor and government incentives, leaving R\&D operations elsewhere. What is worse, domestic capital is even less likely to invest in innovation. The result is that in Romania private sector's share of $\mathrm{R}$ and D spending is up to ten times less than in West European countries with a developed manufacturing sector like Austria or Sweden.

MNCs strategies did not foster much local innovation but what about the state? While state involvement in fostering innovation has been key in success stories from the US to Korea, in Romania the state has actively dismantled the extensive research infrastructure inherited from the years of socialist developmentalism and dramatically cut R and D spending. This is hardly a Romanian characteristic. While average R \& D spending per GDP reaches 2 percent in the EU (with highs of 4 percent in Sweden an Finland), in

\footnotetext{
31 “Romania: Junked by S\&P." Cited in Financial Times, November 29, 2011

${ }^{32}$ Nomura and BIS data cited in Financial Times, November 4, 2011.
} 
Romania it is around $0.5 \%$, a level similar to that of Poland and Slovakia and half the level of Hungary and the Czech Republic.

Joining the EU altered this passive R and D policy and encouraged an increase in R and D spending. While the share of EU funds for $\mathrm{R}$ and $\mathrm{D}$ remained minuscule and the share of the private sector in the total $\mathrm{R}$ and $\mathrm{D}$ investment even declined between 2005 and 2009, the share of the government budget spent on FDI nearly doubled between 2005 and 2009, from 0.5 to 1 percent of the government budget, with universities picking up most of the increase in spending. ${ }^{33}$ This is not bad, when one thinks that as a share of GDP, public spending on $\mathrm{R}$ and $\mathrm{D}$ (aside from universities) was on a par with Sweden and Austria. Yet it was as a result of the EU-assisted austerity package adopted in 2010 that Romania became one of the three EU states that cut public R and D spending. The state worsened this outcome by refraining from using even those innovation policies that have been allowed by Brussels, ${ }^{34}$ such as public acquisitions of innovation-rich products. The state also failed to foster those institutional complementarities between academic research and industry that foster industrial applications.

Overall, Romania's potential to improve its innovation dossier remains limited. ${ }^{35}$ But this owes as much to state weakness as to the strategies of the private sector. While more than half of $R \& D$ in the EU is made by private firms, in Romania this percentage is barely 23 percent, with most R\&D still originating in the public sector. Alternative sources of funding $\mathrm{R}$ and $\mathrm{D}$ are late in arriving. The Bucharest Stock of Exchange does not have the strength to promote equity finance or project finance on an adequate level. ${ }^{36}$ Venture capital for start-ups is scarce and, while improved government access to EU funds could address some of the shortfalls in public funding, progress has been elusive. Take the Capital Risk Fund, for example. This is an EU-funded government initiative that makes available 100 million euros for innovative start-ups whose actual operationalization has been blocked for over three years. In its next two budgets the government inaugurated in late 2008 plans to mobilize the competitiveness funds from the Ministry of the Economy to advance applied research in advanced technology sectors, an initiative that enjoys the support of the business community, yet skepticism reigns among innovating industries about the awareness of pivotal policy players about the importance of R and D.

The argument made popular by the reviewed literature that the Romanian state is too weak for industrial policies meant to upgrade local innovation systems needs to be qualified, however. During the past few years there emerged a few niches of excellence in Romanian industrial policy that the state could build on in the future. This is the case of innovation clusters in the auto and the IT sector, both of which benefited from extensive state aid and income tax cuts and exemptions. In IT, a sector that brings the state half a billion euro a year in tax receipts, industrial policy has been critical via

\footnotetext{
${ }^{33}$ http://epp.eurostat.ec.europa.eu/portal/page/portal/science_technology_innovation/introduction

${ }^{34}$ Steliana Sandu, Michael Dinges (2007): Monitoring and analysis of policies and publicfinancing instruments conducive to higher level of R\&D investments. The "Policy Mix" Project: Country Review Romania, United Nations University, UNU-MERIT, March.

${ }^{35}$ It is interesting some of the greatest fortunes (over a billion euros) have been made by domestic IT entrepreneurs http://www.capital.ro/detalii-articole/stiri/173417.html

${ }^{36}$ Interview with Vincenzo Calla, BNP Paribas, November 8, 2012.
} 
income tax exceptions for the country's 16,000 software programmers. It took extreme duress exercised by the European Commission to convince the government to start considering phasing them out gradually in 2013. This is a sector that ensures full employment: all graduates of computer science departments find work in their field, and this has remained so during the crisis. ${ }^{37}$

Although it accounts for an important part of exports and high-skill employment, the IT sector emerged as a homegrown industry and benefited from foreign capital inflows only from 2004 onwards. Benefiting from a unique set of skills in the region (software engineers with sophisticated polyglot and IT skills) and large classes of computer engineers from the country's public universities, this innovation-heavy sector has recently attracted the likes of Oracle, Microsoft and so on. There is also a homegrown industry in the development of smartphones and tablets whose business strategy is to import them from China and load them with more competitive software with sales in the hundreds of thousands. ${ }^{38}$ Also, some of the wealthiest Romanians are IT entrepreneurs. In 2012 a new government began to budget for adequate finance for start-ups and the coordination of private sector and university research capabilities. ${ }^{39}$

The other example is automotive research, a sector of strategic importance for the comparative advantage of all DMEs (Haiss et al 2009). Renault set of one of its biggest research centers and received extensive state financial support to this end. ${ }^{40}$ Built with local firms, managed largely by Romanian managers and hiring thousands of engineers, Renault Technologie Roumanie (RTG) has design, testing and engineering platforms in three cities. This 450 million euro research center is the biggest of a major European carmaker outside of Europe and some of Renault's 2012 new models were designed to a great extent in Romania. ${ }^{41}$ RTG hires engineering students after training and testing them in internships, with no less than 700 young engineering students taking up this opportunity. The center received from the government 70 million in subsidies as well as government guarantees for a 100 million loan during the 2008-2011 period. In short, Romania not only assembles around one million cars a year, but is developing the capacity to design them. Renault is not alone. Continental (tires and auto parts), Siemens (railway), Alcatel-Lucent (telecom and software), Intel (software), GlaxoSmithKline (pharma), Oracle (software) and Ina Schaeffer (ball bearings) have also spent tens of millions of euros on new R and D centers and hired thousands of engineers there (Dudian 2011).

These are encouraging niches but given the weakness of private sector financing of $\mathrm{R}$ and $\mathrm{D}$, the state has to intervene in a significant way. In order to reach the pledge of 2 percent of GDP by 2020 the government has to contribute to processes that would make possible

\footnotetext{
${ }^{37}$ Ziarul Financiar, November 19, 2012.

${ }^{38}$ http://www.adevarul.ro/actualitate/tech_and_it/Anul_gadgeturilor_romanesti_allview_evolio_infotouch_ebod a_0_810519212.html\#

${ }^{39}$ Interview with Sorin Mandrutescu, chairman of the American Chamber of Commerce, November 8, 2012

${ }^{40}$ Renault Technologie Roumanie has design, testing and engineering platforms in three cities and received from the government 30 million in subsidies as well as government guarantees for a 100 million loan during the

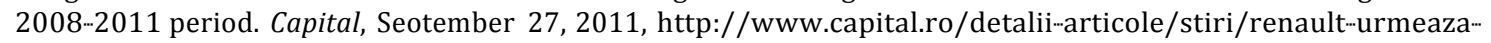

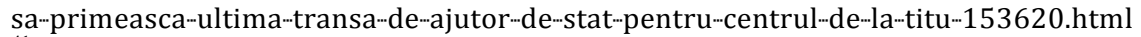

${ }^{41}$ Renault Technologie Roumanie, www.renault-technologie--roumanie.com
} 
3,000 new research posts a year and a seven-fold increase in R\&D spending by the private sector. $^{42}$ For this to happen, Romanian politicians and state managers should perhaps embrace the developmentalist lessons offered by all industrialized countries about the quintessential importance of the state in providing innovation finance (Lin 2011; Janeway 2012). The FDI-driven Romanian export miracle has not landed this economies on the high-octane development path of postwar Finland, Austria or, closer to home, the recent experiences of Singapore, South Korea or Brazil. In these countries, the integration into global supply chains involved making an ideal range of domestically designed products compete in world markets against Western household names. But for that to happen it is not enough to create the macroeconomic, regulatory and infrastructure enticement for foreign investors. One also needs intelligent industrial policies, patient public finance and bold and well-funded public-private partnerships in R\&D that will integrate FDI into medium and long-term development targets defined by the government. Unfortunately, with the possible exception of the Czech Republic, DME reformers either rejected such policies with anti-government fervor or, following the policy fashions of the day, saw them as items of mothballed policy paradigms. The result is that the industrial future of the region looks more like that of Mexico's maquiladoras than that of the Finnish or Korean industrial powerhouses.

\section{Education and training systems}

While institutional reforms point in the direction of an aspiration towards the CME model in Romania, the reality of education and training points towards a clear DME pattern. This section shows that advanced CME institutions that regulate continuous vocational education are not supported by adequate funding from either the state or corporations. Moreover, the results of a recent reform creating CME-style vocational education are yet to produce results.

During the 2000s the Romanian government established institutions that mandated and created incentives for continuous vocational education within the framework of collective bargaining. As a result, vocational training by firms became tax-exempt and firms were expected by the law to provide regular training to their staff. ${ }^{43}$ This regulatory environment was hardly evidence of an arms' length take of the government on workers' skills. Instead, it showed determination to constrain firms to invest in training. ${ }^{44}$ What is

\footnotetext{
${ }^{42}$ Statement by Rolanda Predescu, a director at the government agency in charge o R and D (the National

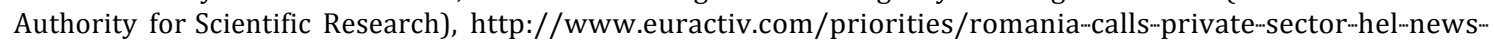
494820

${ }^{43}$ Firms with more than 20 employees are bound by law to prepare and provide, every year, in agreement with the trade union or the employees' representatives, vocational training schemes, which are attached to the collective agreement at company level, as an integral part thereof. Employers are also supposed to create the appropriate conditions for all their employees to take part in vocational training programs at least once every 2 years, if they employ 21 or more employees or at least once every 3 years, if they employ 21 employees or less (Chivu 2009).

${ }^{44}$ Government Decision no. 875/2005 stated that: 'Continuous vocational training (CVT) is not properly supported in the manufacturing industry, with the exception of the big corporations, particularly the multinational ones.' A national survey conducted in 2000 revealed that, in 1999, before the massive influx of FDI, Romanian companies had allocated only $0.5 \%$ of the personnel costs to continuous vocational training. A May 2004 exploratory survey demanded by the EU revealed low firm -llevel investments in training and that only a fourth of the surveyed firms actually organized training programs, and even those who did saw them as expenditure demanded by law rather than as investment in human resources.
} 
more, amendments to the labor code adopted in the mid 2000s demanded that employers and unions establish vocational education training boards and centers meant to address the actual needs of companies and workers and license the vocational training staff. As a result, the number of training programs increased fourfold in a single year. The allencompassing national collective contract for 2007-2010 stipulated that vocational training was mandatory and enforceable. ${ }^{45}$

Before the Lehman moment, it seemed that the government and social partners were moving towards more coordination, although good intentions were not matched with adequate funding for covering the retraining of the unemployed. ${ }^{46}$ The moves towards more coordination were terminated by the structural reforms adopted in the aftermath of the crisis. At the request of an alliance of organized SMEs and multinational capital, supported by the IMF, national collective bargaining and the panoply of continuous vocational education institutions that came with it were terminated. Like its neo corporatism, Romania's continuous vocational education was largely a story of fleeting gains.

Vocational education for new workers has an more marked DME face. The skill revolution carried out by socialism proved to be a major asset for East European economies under capitalism and Romania was no exception. One of the legacies of socialist developmentalism in this country was a dual education system attached to specific industries (Ban 2012). But after 1989 budget cutbacks, poor reform designs and, most importantly, the halving of industrial labor was tantamount to vocational schools with obsolete equipment, a decimated staff and the transformation of these educational institutions into sites of social stigma.

Faced with this situation, governments embraced the then conventional wisdom about the obsolescence of vocational education. A 2003 reform extended the vocational school time to five years (a year longer than in regular high schools) and stressed the study of theoretical disciplines required by the high school graduation exam (bacalaureat). This loaded the already academically weak vocational school students with more tasks than students in high schools. To boot, practical skill cultivation was squeezed from 2 days a week to a few hours. Despite complaining about the shrinking pool of skilled blue-collar workers as a result of mass migration (Ban 2012), ${ }^{47}$ the private sector was late to mobilize to demand changes. Moreover, no longer did vocational school students face

\footnotetext{
${ }^{45}$ The agreement stipulated that when the employer fails to comply with the obligation to provide the funds for the vocational training of an employee, such employee 'is entitled to a paid leave of up to 10 working days or up to 80 working hours, for vocational training purposes.'

${ }^{46}$ On 5 February 2008, the trade unions submitted to the government a proposal for subsidies to be allocated from the unemployment fund for on -the--job training, and for a supplemental amount to the budget of the government labor agency budget for vocational training policies, arguing that, with the current budget, this agency cannot provide for the vocational training of more than 3,000-4,000 employees, while the demand is for some 2 million workers.

${ }^{47}$ Elvira Şeptelean "Romanian Vocational System: A New Beginning/Invatamantul professional din Romania: Un nou inceput" The Romanian Teachers' Association, August 8, 2012, http://www.asociatiaprofesorilor.ro/invatamantul-profesional-din-romania-un-nou-inceput.html; author interview with Florin Pogonaru, president of AOAR, one of the most dynamic employer associations, July 92006.
} 
restrictions to take the bacalaureat and university entrance exams. As a result, vocational school ended up providing de facto general education within a time frame judged necessary for the academically challenged to take the bacalaureat. The denouement was inevitable: enrollment dropped dramatically and only a third of the students managed to graduate. In acknowledgement of system failure, the government dismantled vocational schools altogether in 2009. The result of these transformations was skill mismatch and the massive de-skilling of precisely the range of workers where Romania's comparative advantage was at its highest: mid-level manufacturing. ${ }^{48}$

The Great Recession seems to have triggered a reevaluation of vocational education, however. Nolke and Vliegenthart argue that foreign investors do not have incentives to demand training investments from the state, as the labor they use needs a very modest level of skills. This is not my finding in the case if Romania. Faced with skilled labor shortages, main organizations of foreign capital (AmCham and the Foreign Investors' Council) made the reintroduction of vocational education their main priority. ${ }^{49}$ Their move was successful and in 2012 vocational education was reintroduced, with the German model inspiring the new law and German multinationals spearheading the transformation. By law, employers now play a key role in deciding the number of seats, student training and then employment for this two-year educational system. Indeed, the number of seats is to be determined based on employers' needs and students sign contracts with specific firms. Most of the curriculum is practical and does not allow sitting for the bacalaureat. Vocational students can take the bacalaureat only of they decide to transfer to a high school. To incentivize attendance, a special chapter in the budget was earmarked for scholarships to all vocational school students.

The 2012 reform looks promising. 13,000 students enrolled in 473 vocational schools and, reflecting the overall structure of labor demand, in the fall of 2012 most seats were in engineering. ${ }^{50}$ In the same year engineering departments in universities enrolled 130,000 students, with 10,000 in IT alone. Foreign firms in some economic clusters such as Brasov and Timisoara, both dominated by German manufacturing capital, established their own vocational schools, with students also receiving a scholarship from the firms involved on top of the one received from the government. ${ }^{51}$ Today, the multinational sector began to emphasize vocational education and continues to push towards an even

\footnotetext{
${ }^{48}$ Mary Canning, Martin Godfrey, Dorota Holzer--Zelazewska, "Vocational Education in the New EU Member States," World Bank paper no 116; J.Mitra, "Entrepreneurial and vocational education and training: Lessons from Eastern and Central Europe," Industry and Higher Education, Volume 18, Number 1, 1 February 2004 , pp. 53-61(9)

${ }^{49}$ Interview with Sorin Mandrutescu, Chairman of AmCham Romania, November 8, 2012; American Chamber of Commerce, Priorities for Romania, Bucharest, 2012.

www.amcham.ro/UserFiles/.../Priorities EN FINAL 10251300.pdf; press release by Continental Timisoara, tp://www.conti-.-

online.com/generator/www/ro/ro/continental/pressportal/themes/press_releases/1_topics/others/pr_2012_ 09_17_scoala_profesionala_ro.html; Foreign Investors' Council, Investing in Romania

${ }^{50}$ Interview with Gabriela Liliana Ciobanu, director of the National Center for the Development of Vocational and Technical Education, http://www.scoalaedu.ro/news/684/60/Un-nou-tip--de--invatamant--profesional-fara-"someri

51 "German vocational school prepares students for foreign firms" Income Magazine, September 17, 2012, http://www.incomemagazine.ro/articol_83443/scoala-"profesionala-"germana--pregateste--romani-"pentru-" firmelew.straine.html
} 
deeper involvement of corporations in training. In 2012, the influential AmCham suggested amendments to existing legislation by suggesting that employer organizations send visiting teachers in schools, the introduction of IT education beginning with the kindergarten level, universal access to computers in all schools, mandatory training sessions in firms on a yearly basis, different rules for research and teaching colleges. ${ }^{52}$

So far the paper showed how on the brink of the 2008 crisis Romanian capitalism developed a new institutional equilibrium between the banking sector, manufacturing, innovation and training systems that brought it largely in the line with the DME pattern that Nolke and Vliegenthart observed in East-Central Europe. But rather than disrupt this equilibrium, the post-Lehman crisis reinforced its features, with vocational education being the only notable exception. When the 2011 structural reforms of labor market institutions also terminated Romania's neo-corporatist industrial relations and institutionalized liberal industrial relations, convergence with the DME pattern was virtually complete.

\section{Industrial relations}

Once a heartland of postcommunist labor militancy and then budding neo-corporatism, during the Great Recession industrial relations in Romania have reinforced the institutional complementarity specific to both DMEs and LMEs: mid-level regulation and predominantly firm-level collective bargaining. Given the high perceived political costs of labor resistance, it took the extreme economic and political circumstances provided by the Great Recession for an emerging alliance between state and organized multinational capital to bring Romanian industrial relations in line with those of its regional competitors. The labor deregulation blitzkrieg undertaken in 2011 is a case in which the crisis enhanced the political power resources of liberalizing actors, enabling them to overpower the neocorporatist coalition between domestic labor and capital that defended the unionized sphere of the labor market against commodification.

Since the adoption in 2003 of pro-worker labor legislation (Trif 2004; 2005; 2007; 2008), a move aimed at re-embedding labor market exchanges in society, conservative politicians and domestic small businesses organizations have reinforced the demands of the IMF, the World Bank and multinational capital's organizations (Federation of Foreign Investors and American Chamber of Commerce) that this legislation be scrapped and replaced with best practices endorsed by the Bretton Woods institutions. Opposing this position were all labor unions, the bulk of domestic employer associations and the left wing of the Social-Democratic Party, under whose government the pro-worker legislation had been adopted.

Before 2011, labor market deregulation had a story of failures in Romania. It had become part of IMF conditionality in 2004 and was eventually supported by an exiting Social Democratic government whose resolve was weakened by the existence of a strong liberal

\footnotetext{
${ }^{52}$ AmCham Romania, "AmCham Comments on the National Strategy for Education and Research in the Knowledge Society" www.amcham.ro
} 
faction and fear that a failed relationship with the IMF could negatively affect Romania's application for EU membership. In 2004 the Fund demanded that a World Bankapproved international expert draft the new code and asked the government to adopt the new code during the term of the stand-by agreement with Romania. The advent of a conservative government in 2005 whose economic ideology stressed economically libertarian themes strengthened this pro-deregulation coalition and in its first month in office the new government announced that it would adopt the World Bank-approved legislation.

Yet the coordinated action of labor unions, their capacity to mobilize external support from West European unions and particularly the credibility of union threats ensured by the memory of extensive labor militancy during the 1990s (Munteanu 2003) made the government adopt a much more moderate labor reform in 2006, with union consent (Pilat 2008). The mass migration of the labor force in EU member states in the late 2000s and the subsequent drying up of excess labor further weakened the case for the kind of "big bang" deregulation that the liberal coalition of domestic and external interests wanted.

In their brief analysis of Romania and Bulgaria during the crisis, Bohle and Greskovits (2012: 252) argue that in contrast to the Baltic countries, during the post-Lehman crisis the governments of these two states were "drifting and inconsequential in their policy responses and have been frequently challenged by massive protests waves." At least when it comes to industrial relations in Romania this claim needs updating. For despite labor protests and, at least initially, the protestations of the biggest domestic employer organizations, in 2011 the conservative government of Emil Boc used an emergency procedure in the Parliament to undertake the most extensive deregulation of Romanian industrial relations ever recorded. Collective bargaining legislation was drastically changed: national level bargaining was eliminated, labor-capital relations are now limited largely to the firm level, union representatives lost their protections, firing became easy and temporary contracts and work conditions were freed from union intervention procedures (Domnisoru 2012). A new left-of-center government elected in November 2012 on a wave of popular resentment against austerity and structural reforms has offered no evidence that the 2011 labor reforms stand to be reversed, thus locking Romania in the DME model on this front as well.

\section{Conclusions}

This paper suggests that there is overwhelming evidence to argue that Romanian capitalism has converged with the dependent market economy model detected by scholars in East-Central Europe. Like Poland, Czech Republic, Poland and Slovakia, Romania has an economy dependent on FDI and financial flows that entails a significant degree of state-business coordination while excluding labor. These movements of capital made possible its economic boom during the 2000s, caused sharp increases in productivity and export complexity, slowed down the pace of deindustrialization and carved out niches of industrial excellence. In contrast to the Baltics' radical skepticism about industrial policy, Romanian governments adopted a consistent set of FDI-oriented industrial policies that have experienced further reinforcement since 2008. But Romania 
also replicated the other face of the DME model: a financial system largely divorced from the export industries, poor domestic innovation capabilities and low investments in the education and skills of domestic labor. Similarly, alliances between state and foreign capital removed peak level collective bargaining and a pro-worker labor code, two institutional pillars that had made Romania less rather than more DME-like. This development is significant in the light of Streeck's Polanyian plea (2012: 36-37) that after the crisis the comparative study of capitalism should assign a more prominent place to conflict and contradiction in addition to and probably prior to cooperation and coordination.

Yet the paper's findings reach beyond the case of Romania by tracking down mechanisms of dependence that do not appear in existing research and by qualifying some of its insights. Most of the new aspects of dependence can be found in the banking sector. Daniela Gabor's remark that Romania is a "dependent financialized economy" is both apt and potentially applicable to other DMEs (Gabor 2012). When the crisis struck, the subsidiaries of foreign banks that controlled the financial sector had both the incentives and the capacity to execute a run on the Romanian currency. Moreover, they threatened to help their "mother banks," draining a large part of the country's money supply. In exchange for these banks' maintaining their exposure, the Romanian government accepted an international public-private crisis resolution regime managed by the IMF and the EU that co-opted the banks in the mechanisms of policy surveillance. In this way, foreign banks added a new layer of dependence than the ones identified in the literature. Finally, the same public-private international regime successfully protected the subsidiaries of foreign banks against domestic regulatory interventions and consumer group campaigns. Constrained by an internationally monitored fiscal consolidation package, with its money supply sold to transnational banks periodically shattered by sovereign debt downgrades in their states of origin and faced with a massive collapse of FDI, Romanian governments had dwindling resources to make domestic capitalism less dependent even if they had the capacity and the ideological proclivity to do so. For reasons that future research has to clarify, they had neither of these.

The paper also qualifies some of the findings of the literature on dependent market economies. The argument that MNCs have no incentives to invest in local innovation systems is supported by evidence overall but it needs to be qualified by an analysis of the automotive and IT sector, This analysis suggests that MNCs can be made to do so through smartly targeted industrial policies. Similarly, the lack of interest of MNCs in vocational education posited in the literature appears challenged by the case of Romania. The paper's findings suggest that labor shortages in a low-wage but increasingly complex export-oriented industry spurred MNCs to invest resources in vocational education reform. Given the emergence of such shortages in the other aging societies from the region, this development may become a new DME feature

In a broader sense, the paper's findings may contribute to ongoing debates on the divide between neo-developmental and liberal economic models. Unlike in the case of open economy neo-developmental states (Ban 2012), in Romania's dependent capitalism the state has an uneven capacity to create synergies between FDI, national development goals and the competitiveness of domestic capital. Furthermore, unlike in the case of post- 
Soviet developmental states, where state-oligarch bargains were centralized and systemic (Wengle 2012), in Romania the state's accommodation of the interests of domestic capital has been done in a fashion that was too ad-hoc and too decentralized to establish solid domestic anchors for improved employment, growth and global competitiveness.

Future analyses of the dynamic of East European capitalisms during the crisis can benefit from Polanyians' insight that the social integration necessary for securing a functioning economy can be at odds with the profitable efficiency of the institutions that capitalists may be able to construct voluntarily for their own benefit. This means a better balance between attention paid to production regime (stressed by VOC) and the political regimes governing capitalism. This means that the literature on capitalist diversity may need a new continuum between Martin and Thelen's (2007) emphasis on the role of politics in the coordination of capitalist economies and Streeck's (2012) demand that politics should be construed more broadly than the supply of institutions geared towards more efficient and competitive production.

\section{Bibliography}

Adam, Frane, Primovz Kristan, and Matevvz Tomvsivc. 2009. "Varieties of Capitalism in Eastern Europe (with Special Emphasis on Estonia and Slovenia)." Communist and Post-communist Studies 42 (1): 65-81.

Ban, C. 2011. "Neoliberalism in Translation: Economic Ideas and Reforms in Spain and Romania.” http://drum.lib.umd.edu/handle/1903/11456.

Ban, Cornel. 2012. "Brazil's Liberal Neo-developmentalism: New Paradigm or Edited Orthodoxy?" Review of International Political Economy: 1-34.

doi:10.1080/09692290.2012.660183.

2012. "Sovereign Debt, Austerity, and Regime Change The Case of Nicolae

Ceausescu's Romania." East European Politics \& Societies 26.4 (2012): 743.. 776.

Becker, Joachim, and Johannes Jäger. 2010. "Development Trajectories in the Crisis in Europe." Debatte: Journal of Contemporary Central and Eastern Europe 18 (1):5-27.

Birch, K., and V. Mykhnenko. 2009. "Varieties of Neoliberalism? Restructuring in Large Industrially Dependent Regions Across Western and Eastern Europe.” Journal of Economic Geography 9 (3): 355-380.

Bohle, D., and B. Greskovits. 2012. Capitalist Diversity on Europe's Periphery. Cornell University Press.

Bruff, Ian, and Laura Horn. 2012. "Varieties of Capitalism in Crisis?" Competition \& Change 16 (3): 161-168. doi:10.1179/1024529412Z.00000000011. 
Canagarajah, Sudharshan, Martin Brownbridge, Anca Paliu, and Ionut Dumitru. 2012. "The Challenges to Long Run Fiscal Sustainability in Romania". SSRN Scholarly Paper ID 1979288. Rochester, NY: Social Science Research Network. http://papers.ssrn.com/abstract=1979288.

Cardoso, Fernando Henrique, and Enzo Faletto. 1979. Dependency and Development in Latin America. University of California Press.

Cernat, Lucien. 2006. Europeanization, Varieties of Capitalism and Economic Performance in Central and Eastern Europe. Palgrave Macmillan.

Crowley, Stephen, and Miroslav Stanojević. 2011. "Varieties of Capitalism, Power Resources, and Historical Legacies: Explaining the Slovenian Exception." Politics \& Society 39 (2): 268-295.

Van Der Pijl, Kees. 2001. "From Gorbachev to Kosovo: Atlantic Rivalries and the Reincorporation of Eastern Europe." Review of International Political Economy 8 (2): 275-310.

Domnisoru, C. 2012. "Decent work policy options for the Romanian economy." No. 472564. International Labour Organization.

Drahokoupil, Jan, and Martin Myant. 2012. "Putting Comparative Capitalism Research in Its Place: Varieties of Capitalism in Transition Economies, SSRN Scholarly Paper ID 2055200, http://papers.ssrn.com/abstract $=2055200$.

Drechsler, W., R. Kattel, and E. Reinert. 2011. Techno-economic Paradigms: Essays in Honour of Carlota Perez. Anthem Press. 1hB\&sig=uTPAC2Os1dgZgxIyD7Sap6kXgkE.

Dudian, M. 2011. "Innovative Clusters: The Case Of Romania.” Management Research and Practice 3 (3): 1-11.

Duman, Anil, and Lucia Kureková. 2012. "The Role of State in Development of Socioeconomic Models in Hungary and Slovakia: The Case of Industrial Policy." Journal of European Public Policy 19 (8): 1207-1228.

Ebenau, Matthias. 2012. "Varieties of Capitalism or Dependency? A Critique of the VoC Approach for Latin America." Competition \& Change 16 (3): 206-223.

Farkas, Beáta. 2011. "The Central and Eastern European Model of Capitalism.” Post- Communist Economies 23 (1): 15-34.

Feldmann, Magnus. 2006. "Emerging Varieties of Capitalism in Transition Countries Industrial Relations and Wage Bargaining in Estonia and Slovenia." Comparative Political Studies 39 (7): 829-854. 
Gabor, D. 2010. “(De) Financialization and Crisis in Eastern Europe.” Competition \& Change 14 (3-4): 3-4.

Gabor, D. V. 2012. "The Road to Financialization in Central and Eastern Europe: The Early Policies and Politics of Stabilizing Transition." Review of Political

Economy 24 (2): 227-249.

Gabor, D, 2012. "The Financialization of the Romanian Economy.” FESSUD report. Gabor, Daniela, and Zdenek Kudrna. "Political risk, crisis and foreign $\cdots$ owned banks in New Member states." Europe Asia Studies (2012).

Haar, Laura N., and Nicolae Marinescu. 2011. "Energy Policy and European Utilities' Strategy: Lessons from the Liberalisation and Privatisation of the Energy Sector in Romania." Energy Policy 39 (5) (May): 2245-2255.

Haiss, Peter, Bernhard Mahlberg, and Michael Molling. 2011. "The Automotive Industry in Central and Eastern Europe - Engine of Grow or Free Rider?" SSRN Scholarly Paper ID 1805968. Rochester, NY: Social Science Research Network. http://papers.ssrn.com/abstract=1805968.

Hall, P. A., and D. W. Gingerich. 2009. "Varieties of Capitalism and Institutional Complementarities in the Political Economy: An Empirical Analysis." British Journal of Political Science 39 (3): 449-482.

Hall, P. A., and D. W. Soskice. 2001. Varieties of Capitalism: The Institutional Foundations of Comparative Advantage. Wiley Online Library.

Hall, P. A., and K. Thelen. 2009. "Institutional Change in Varieties of Capitalism." Socio-Economic Review 7 (1): 7-34.

Heidenreich, Martin. 2012. Innovation and Institutional Embeddedness of Multinational Companies. Edward Elgar Publishing.

Hübner, Kurt. 2011. "Baltic Tigers: The Limits of Unfettered Liberalization.” Journal of Baltic Studies 42 (1): 81-90.

Khan, Shahrukh Rafi, and Jens Christiansen. 2010. Towards New

Developmentalism: Market as Means Rather Than Master. Vol. 83. Routledge.

Knell, M., and M. Srholec. 2006. "Emerging Varieties of Capitalism in Central and Eastern Europe." Varieties of Capitalism in Post-Communist Countries.

http://www.economicpolicy.eu/KnellSrholec2005Emergingvarietiesofcapitalismin CEE.pdf.

—. 2007. "Diverging Pathways in Central and Eastern Europe." Varieties of Capitalism in Post-communist Countries: 40-62. 
Kohli, Atul. 2009. "Nationalist Versus Dependent Capitalist Development: Alternate Pathways of Asia and Latin America in a Globalized World." Studies in Comparative International Development (SCID) 44 (4): 386-410.

Lane, D. 2005. "Emerging Varieties of Capitalism in Former State Socialist Societies." Competition \& Change 9 (3): 227-247.

Lin, J. Y. 2011. "New Structural Economics: a Framework for Rethinking Development." The World Bank Research Observer 26 (2): 193-221.

Martin, Cathie Jo, and Duane Swank. 2012. The Political Construction of Business Interests: Coordination, Growth, and Equality. Cambridge University Press. Myant, M., and J. Drahokoupil. 2010. "Varieties of Capitalism in Transition Economies." Available at SSRN 1561944. http://papers.ssrn.com/sol3/papers.cfm?abstract_id=1561944.

- 2012. "International Integration, Varieties of Capitalism and Resilience to Crisis in Transition Economies." Europe-Asia Studies 64 (1): 1-33.

Mykhnenko, V. 2005. "What Type of Capitalism in Post-communist Europe? Poland and Ukraine Compared." In ESEMK Workshop on Forms of Capitalism in Central and Eastern European Countries in Transition, 4th March. http://www.policy.hu/mykhnenko/What_Type_of_Capitalism_in_Eastern_Europe _Draft.pdf.

Nölke, A., and A. Vliegenthart. 2009. "Enlarging the Varieties of Capitalism: The Emergence of Dependent Market Economies in East Central Europe." World Politics 61 (4): 670-702.

Nousios, Petros, Henk Overbeek, and Andreas Tsolakis. 2012. Globalisation and European Integration: Critical Approaches to Regional Order and International Relations. Routledge.

Onaran, Özlem. 2011. "From Transition Crisis to the Global Crisis: Twenty Years of Capitalism and Labour in the Central and Eastern EU New Member States." Capital \& Class 35 (2) (June 1): 213-231. doi:10.1177/0309816811402648.

Peck, Jamie, Nik Theodore, and Neil Brenner. 2010. "Postneoliberalism and Its Malcontents." Antipode 41 (s1): 94-116.

Pilat, Ninucia-Maria. 2006. "Trade Unions and the Amendment of the Labour Code in Romania." Perspectives on European Politics and Society 7 (2): 185-203.

Schmidt, V. A. 2009. "Putting the Political Back into Political Economy by Bringing the State Back in yet Again," World Politics 61 (3): 516-546. 
Schneider, Ben Ross. 2009. "Hierarchical Market Economies and Varieties of Capitalism in Latin America." Journal of Latin American Studies 41 (3): 553-575.

Schneider, Ben Ross, and David Soskice. 2009. "Inequality in Developed Countries and Latin America: Coordinated, Liberal and Hierarchical Systems." Economy and Society 38 (1): 17-52.

Sokol, Martin. 2001. "Central and Eastern Europe a Decade After the Fall of Statesocialism: Regional Dimensions of Transition Processes.” Regional Studies 35 (7): $645-655$.

Thelen, K. 2012. "Varieties of Capitalism: Trajectories of Liberalization and the New Politics of Social Solidarity." Annual Review of Political Science 15: 137-159. Trif, A. 2004. "Overview of Industrial Relations in Romania." SEER-South-East Europe Review for Labour and Social Affairs (02): 43.

- 2005. "Collective Bargaining Practices in Eastern Europe: Case Study Evidence from Romania”. MPIfG working paper. https://opus.zbwkiel.de/dspace/handle/10419/41657.

- 2007. "Collective Bargaining in Eastern Europe: Case Study Evidence from Romania.” European Journal of Industrial Relations 13 (2): 237-256.

- 2008. "Opportunities and Challenges of EU Accession: Industrial Relations in Romania.” European Journal of Industrial Relations 14 (4): 461-478.

Voinea, Liviu. 0. "Revisiting Crisis Generators in Romania and Other New EU Member States." Review of International Political Economy: 1-30. doi:10.1080/09692290.2012.733315.

Wengle, Susanne A. 2012a. "Post-Soviet Developmentalism and the Political Economy of Russia's Electricity Sector Liberalization.” Studies in Comparative International Development (SCID): 1-40. 